\title{
At blive til en ligeværdig dansk kvinde - fortællinger om race, køn og heteroseksualitet
}

\section{Af Lene Myong Petersen}

Én dimension af menneskelig tilblivelse bandler om racialiseret forskelssatten. Om at blive ind-og udsluset $i$ raciale kategorier. Hvilke betydninger tilskrives kategorier af asiatisk femininitet $i$ en dansk kontekst? $O g$ bvordan erfares og forbandles disse tilblivelsesprocesser af voksne koreansk adopterede kvinder?

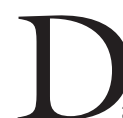

a jeg interviewer Hanne, fortæller hun om sine erfaringer med at gå i byen. Hanne har lagt mærke til, at det altid er lidt ældre mænd, som udviser interesse og kommer hen til hende. I interviewet funderer Hanne over, om det mon har noget at gøre med hende som person, eller om det har noget at gøre med hendes udseende? Om sine oplevelser i forbindelse med (heteroseksuel) dating forklarer Hanne:

"Der har jeg hort meget om mit udseende. Der har jeg hort meget om, at jeg var lidt eksotisk. Der var lidt thailandsk over det. Og det kan man godt blive saidan lidt over bagefter, ikke? Det var ikke min personlighed, det var mit udseende, de tendte pà.”

Hannes fortælling om seksualitet, race og køn indgår i et kvalitativt empirisk forskningsprojekt om transnational adoption, fra Korea til Danmark, og racialiseret tilblivelse, hvortil der er interviewet 35 voksne kor- 
eansk adopterede (Myong Petersen 2009). ${ }^{1}$ Hannes erfaring - at hun i visse situationer kategoriseres som thailandsk - peger på et generelt mønster i de kvindelige informanters fortællinger. Et mønster der analytisk kan sammenfattes i en diskursiv figur: Den Thailandske Kvinde. ${ }^{2}$ Figuren trækker forskellige konnotationer med sig: sexturisme, xgteskabsmigration, prostitution, seksuelt tilgængelig, eksotisk objekt eller slet og ret undertrykt.

I denne artikel vil Den Thailandske Kvinde blive begrebsliggjort som både analytisk figur og diskursiv tilblivelsesproces - i et skæringspunkt hvor race, køn og seksualitet gensidigt informerer hinanden, og hvor andetgørende processer af eksotisering og hyperseksualisering definerer og mærker levede kategorier af asiatisk ${ }^{3}$ femininitet. Hvordan erfares disse tilblivelsesprocesser af informanterne? Hvordan forhandles og omarbejdes de? Og hvad fortæller en figur som Den Thailandske Kvinde om racialiseret kønsmagt i Danmark? Med teoretisk afsæt i poststrukturalistisk feministisk kønsteori er artiklens sigte tosidet: Dels at fremskrive en analytisk figur på baggrund af informanternes fortællinger, dels at undersøge hvordan og med hvilke konsekvenser informanternes tilblivelsesprocesser artikuleres (men også forhandles) gennem denne figur.

\section{RACIALISERET SUBJEKTIVERING}

Teoretiske og metodologiske overvejelser omkring køn og etnicitet har i nogen grad domineret dansk kønsforskning, mens spørgsmål om køn og race har fyldt mindre. ${ }^{4}$ Nedtoningen af race som analytisk relevant kategori må delvist anskues som en konsekvens af det 20. århundredes europriske omgang med et biologisk racebegreb (Andreassen 2007, 2005, Myong Petersen 2009). Der kan dog være en pointe i at insistere på både teoretisk og analytisk begrebsliggørelse af racialiseret tilblivelse og racialiseringsprocesser, da dette vil ud- bygge og præcisere de indsigter, som bliver resultatet af en fokusering på etnicitet.

I USA har sociologer som Howard Winant og Michael Omi opnået stor indflydelse i forhold til at anskueliggøre race som et strukturelt socialitetsorganiserende princip og racialisering som mulighedspræmis for det senmoderne menneske (Omi og Winant 1994 [1984]). Omi og Winant beskæftiger sig ikke med, hvordan det enkelte subjekt, situeret $i$ en kontekst af hverdagsliv, forhandler de forskellige former for racialisering, men udfordringen er blevet taget op af lang række kvalitative forskere. Og her anvender mange racialisering som en betegnelse for, hvordan mennesker vedvarende anråbes gennem diskursivt konstruerede raciale kategorier; processer der udlægger forskellige betingelser for subjektivitet og agens (se f.eks. Berg 2004, Dorow 2006, Frankenberg 1993, Manalansan 2004, Patton 2000, Phoenix 2005). I en sådan optik forstås race ikke som essensbetinget forskelsmarkør, men derimod som kropsliggjort effekt af varierende, kontekstuelle og historisk sedimenterede racialiseringsprocesser (Hübinette og Tigervall 2008). Racialisering tænkes i den forstand som en både konstrueret og forhandlet proces, men også som uomgængelig forskelssættende komponent i de diskursive processer, der producerer subjektivitet.

Jeg finder det oplagt at knytte en sådan forståelse af racialisering til et subjektiveringsbegreb i traditionen fra Michel Foucault og Judith Butler. ${ }^{5}$ Sidstnævnte anfører, at subjektivering griber det forhold, at subjektet underkastes den diskursive magt, men også at selvsamme magt fungerer som subjektets eksistensbetingelse (Butler 1997). Subjektiveringsbegrebet giver derved mulighed for teoretisk og analytisk fremskrivning af de sociale processer og diskursivt-materielle praksisser, som former og udlægger betingelserne for subjektivitet og menneskelig tilblivelse. I en dansk kontekst af kvalitativ kønsforskning har eksempelvis Dorte Marie Søndergaard (2005, 2003, 
2002, 2000) arbejdet på at operationalisere subjektiveringsbegrebet $\mathrm{i}$ analyser af levet hverdagsliv. ${ }^{6}$ Tanken er her, at subjektivering ikke skal forstås som subjektivitetsdeterminerende; subjektet 'arbejder tilbage' på diverse subjektiveringsprocesser.

Det er værd at bemærke, at racialiseret subjektivering ikke kun handler om de processer, hvormed subjekter kaldes til eksistens gennem essentialiserende raciale kategorier (bvide europeere har lavere intelligens end sorte afrikanere). Processer der meget tydeligt afstedkommer kropslig differentiering og hierarkisering. Racialiseret subjektivering kan også antage form som racial afsværgelse (race betyder absolut intet), der konstruerer essentialiserende enshed og assimilation til en farveblind norm. Sådanne subjektiveringer må forstås som historiske; kontekstuelt og temporalt forankrede, men ikke nødvendigvis som gensidigt ekskluderende. Tværtimod kan racialiseret subjektivering oplagt anskues som en flertydig og modsætningsfyldt processualitet. I denne artikel vil Den Thailandske Kvinde blive fremanalyseret som en racialiseret subjektiveringsproces, der informeres af kategorier som køn og seksualitet, men som også forhandles og modarbejdes på forskellige måder.

\section{Den Thailandske Kvinde}

Som figur kan Den Thailandske Kvinde oplagt anskues som et produkt af globaliserede migrationsmønstre og vestlig masseturisme til Thailand. Men det er også en figur, som er lokalt forankret i en nordeuropæisk og måske især skandinavisk kontekst, hvor xgteskabs- og prostitutionsrelateret migration fra Thailand jævnligt optræder i masseog nyhedsmedier. ${ }^{7}$

En informant, Simone fortæller, at da hun blev teenager, lagde hun mærke til, at de jævnaldrende (hvide) drenge, hun kendte fra sin skole, ikke udviste nogen særlig romantisk interesse for hende. Anderledes forholdt det sig med interessen fra voksne (hvide) mænd:
"I det hele taget så kunne jeg sådan merke fra dem, som var jevnaldrende, drenge og fyre, de kiggede ikke på mig med den interesse, som de kiggede på andre piger. Og så opdagede jeg bare, at nogle aldre eller voksne mand kiggede på mig."

Som vi kan høre, konfigureres der for teenageren Simone en seksuel og romantisk usynlighed i de skole- og fritidskontekster, hun færdes i blandt jævnaldrende. Derimod bliver hun seksuelt synlig i andre relationer og blikke. Synligheden følges af varsomhed. Simone fortæller, at hendes adoptivmor i denne periode er mere bekymret for hende end for Simones ikke-adopterede (hvide) søstre. I samme tidsrum flytter der en del thailandske kvinder til det område, hvor Simone og hendes familie bor, og Simone husker, at hendes adoptivmor forsøger at forberede hende på, hvad det kan betyde:

"Hun sagde (.) sådan til mig... Og det er rigtig nok, altsä hvis jeg går med en virkelig kort nederdel, så skal jeg (.) ikke vere overrasket over, hvis jeg fär nogle underlige kommentarer. Fordi andre, som står udenfor og ikke ser eller kender mig, de vil sikkert bare tro, at jeg også var en kvinde fra Thailand, som var kommet til. Og det var risikoen. Altsà, det advarede bun mig mod. Eller hun gjorde mig opmerksom på det.”

Den advarsel og/eller gode råd, som Simones adoptivmor her formulerer, spænder over en kompleksitet. Der udtrykkes ængstelse over, at Simones krop kan risikere at blive betydningsindskrevet som 'en kvinde fra Thailand'. Og dermed at der produceres enshed mellem Simones krop og en kropsliggjort kategori af 'kvinde fra Thailand'. Ensheden modvirkes gennem etablering af forskellighed og distance (mellem Simone og 'kvinde fra Thailand'). Det er Simone, som ansvarspålægges for at opretholde denne forskellighed ved ikke at gå i korte nederdele.

I fortxllingerne kobles erfaringerne af at 
blive (gjort) til en thailandsk kvinde i høj grad sammen med teenageårene og indgangen til en livsfase, hvor seksuelle identiteter, praksisser og relationer forventes opsøgt og udforsket. I tidsrummet for interviewproduktionen er informanterne fra midt i 20'erne til midt i 30'erne, og de er ikke længere på vej ud i et seksuelt og romantiseret praksisfelt, men har allerede gjort sig erfaringer i dette praksisfelt gennem en årrække. I egen selvforståelse er de på vej ud af diskoteket og ind (hvis ikke allerede etableret) i familie- og kærlighedsliv. Mange har børn og faste parforhold. Sammenfaldet mellem købt og/eller prostitueret og så et specifikt racialiseret kropstegn erfares dog stadig som virksomt; et sammenfald der kan begrebsliggøres som en kompleks og fikserende racialiseringsproces, der producerer ambivalente følelser af vrede, provokation og medlidenhed. Da jeg interviewer Linnea, fortæller hun:

"Fordi jeg må indrømme, de kvinder, som jeg ser $i$ Danmark, der er kommet hertil på mandens premisser, fx unge thailandske kvinderman moder nede $i$ byen og ser dem komme gående haind $i$ hånd med en aldre (.) eller midaldrende dansk mand - og hvor man tenker, at det er hojst sandsynligt én, han har fået sendt normest (.) Det der provokerer mig, det er, at $i$ det hele taget at en mand kan tro, at han på den måde kan købe sig til noget. Men også at jeg et eller andet sted går ud fra, jeg har nogle fordomme om det - det er meget sterke fordomme - om at de måske er mand, som har svert ved at takle det at vere $i$ et forhold til en ligevardig kvinde. Fordi en ligevardig kvinde vil sige dem imod og vil ikke bare tilpasse sig manden. Hun vil ogsa have sine egne onsker, om hvordan tingene skal vare. Der har jeg en eller anden fordom om, at de her mond, er den slags mend, som gerne vil have en, de kan styre. En de gerne vil kontrolleve. Og så omvendt så tonker jeg også, at mange af de mond er sikkert nogle dybt ulykkelige mand, som maiske har svert ved overhovedet at skabe kontakt til en dansk kvinde, som vil fremstå som meget sterk og meget handlekraftig, dem der ofte har bukserne på $i$ et forhold."

De 'thailandske kvinder', som optræder i Linneas fortælling, konnoterer købt og afsendt. I mange interview fremstår købt og prostitueret som overlappende men ikke altid fuldt synonyme positioner: Købt betegner aktører, der prostituerer sig, men købt indbefatter også aktører, der migrerer for at indgå xgteskab (ofte italesat som 'postordre-koner'). Forskellige grader af seksuel promiskuøsitet og kommodificering mærker disse subjektpositioner, og det skaber en offerposition, som Linnea og mange af de øvrige informanter distancerer sig fra og provokeres af. Sandsynligvis fordi offerpositionen konnoterer manglende agens, manglende selvstændighed og ikke mindst manglende værdighed.

Vi kan forfølge Linnea og de andre informanters distanceringsbevægelser ud fra en antagelse om, at historisk sedimenterede fortællinger om Den Prostituerede generelt fungerer som truende men også konstitutiv yderside til normative konstruktioner af middelklassefemininitet. ${ }^{8}$ Det falder mig dog ind, at distanceringsbestræbelserne ikke udelukkende og entydigt kan aflæses som en modarbejdning i forhold til, at Den Thailandske Kvinde hverver informanterne til en kulturelt stigmatiseret kategori som prostitueret i hverdagsbetydningen; en kvinde der sælger sex til en køber.

For i Linneas fortælling er det først og fremmest et strukturelt og asymmetrisk magtforhold, der tydeliggøres, når ældre, hvide, vestlige mænd går hånd $\mathrm{i}$ hånd med væsentligt yngre, asiatiske, ikke-vestlige kvinder. Vi kan overveje, om det er aktualiseringen og fremløftningen af denne asymmetri $i$ en relation, der ikke kun handler om en decideret sexhandel mellem en prostitueret og en prostitutionskunde, der erfares som destabiliserende og provokerende? Asymmetrien hægter sig op på mange kategorier - køn, race, klasse, alder, globalisering - og den vanskeliggør mere agensdefi- 
nerede læsninger af Den Thailandske Kvinde. En sådan læsning peger i retning af, at aktualisering af et (meget tydeligt) over- og underordningsmønster, og herunder henvisningen til en position som underordnet, kommer i konflikt med de kønsidentiteter og kærlighedsidealer, som Linnea og de kvindelige informanter mere generelt indforstår sig med.

\section{THAILANDSK OG ULIGEVÆRDIG, DANSK OG LIGEVÆRDIG}

Forfølger vi nu disse pointer, så kan de mange distanceringer til Den Thailandske Kvinde læses som en afstandtagen til et kønsmagtsystem, der gennemfarves af en klar magtfordeling mellem 'mand' og 'kvinde', hvor førstnævnte er overordnet sidstnævnte. Linnea betvivler, at de ældre, hvide, danske mænd, der gifter sig med unge thailandske kvinder, er i stand til at indgå i relationer til en 'stærk' dansk kvinde; at de vil kunne hævde sig i sådanne forhold. I Linneas fortælling sammenkobles kategorien dansk kvinde med karakteristika som 'stærk' og 'handlekraftig'. Den 'ligeværdige kvinde' er i stand til at sige imod og kæmpe for sin ret, og denne kvinde markeres af en specifik etnicitet: 'danskhed'. Konstruktionen af Den (ikke-danske) Thailandske Kvinde informeres modsat af uligeværd; af en manglende mulighed for ikke at kunne sige imod og ikke kunne bestemme, hvor skabet skal stå. Linnea står ikke alene med sin investering i ønsket om ligeværd, ligestilling og en kønsidentitet, der karakteriseres af selvbestemmelse, uafhængighed og handlekraft. Generelt taler de kvindelige informanter sig selv frem som investerede $i$ relationer, der bygger på idealer om kønsegalitarisme og ligeværd.

I sit studie af seksualiseringspraksisser blandt skoleelever argumenterer Sarah Højgaard Cawood (2007) for, at diskursiveringer af ligestilling som en særlig dansk værdi făr konsekvenser for nogle af de maskuline aktører, der ikke kan eller vil påberåbe sig en dansk identitet. Pågældende aktører erfarer vanskeligheder med at blive aflæst som interesserede og investerede i kønsligestilling og dermed få adgang til subjektpositioner, der konnoterer 'moderne maskulinitet'. De ekskluderes og underordnes gennem mistanken om (essentialistisk) mandschauvinisme. I den forstand er kønsligestilling en stærkt etnificeret kategori, der fra den dominerende kulturs side i stigende grad anvendes som en lakmustest på, om individer med minoritetsbaggrund både lader sig og selv ønsker at blive integreret i det danske samfund, og dermed om de (aktivt) gør sig fortjent til betegnelsen dansk (ibid.).

Mine informanters fortællinger peger også i retning af, at kønsligestilling må anskues som en etnisk-racialiseret konstruktion og ideal. For Linnea og mange af de øvrige informanter får deres racialiserede (asiatiske) kropstegn betydning for, hvorvidt de ekskluderes fra en majoriserende (hvid) kategori som 'danskhed' og dermed fra positioneringer som 'stærke' og 'ligeværdige' kvinder. Med en racialiseret påstand om uligeværd (at man som asiatisk kvinde er svag og ikke kan fortælle, hvor skabet skal stå) konfigureres underordning og uværdighedsfølelser for mange af informanterne, fordi der navigeres i forhold til et ideal om kønsligestilling.

\section{UPASSENDE SEKSUALITET}

Fikserings- og stigmatiseringspotentialet ved Den Thailandske Kvindes artikuleres i høj grad via et seksualiseret register. Og det er værd at holde sig for øje, for i en dansk kontekst betydningstilskrives kategorien måske først og fremmest som (seksualiseret) 'forræder' i forhold til et herskende ideal om kønsligestilling; et ideal der i bredere samfundsmæssige diskurser gestaltes som fuldt realiseret mellem danske (hvide) mænd og danske (hvide) kvinder.

Som figur befinder Den Thailandske Kvinde sig i periferien af et racialiseret femi- 
ninitetshierarki. Her kan vi tænke, at Den Thailandske Kvinde indtager en parallel position til Den Muslimske Kvinde, der konstrueres som grundlæggende undertrykt i et monolitisk muslimsk patriarkats navn. Dette billede af Den Muslimske Kvinde, som altid undertrykt og uligestillet, understøtter forestillinger om Den Hvide Danske Kvinde som frigjort og ligestillet (Andreassen 2007, 2005). Men hvor Den Muslimske Kvinde især konstrueres som undertrykt, fordi hun tænkes afskåret fra på frivillig og lystbetonet basis at indgå seksuelle relationer (med Den Hvide Danske Mand), konstrueres Den Thailandske Kvinde som undertrykt, netop fordi hun tænkes alt for villig til at indgå og opsøge seksuelle relationer (med Den Hvide Danske Mand).

Man kan altså sige, at subjektiverende kategorier som Den Thailandske Kvinde og Den Muslimske Kvinde begge tjener som konstituerende, om end forskellige, ydersider til fantasien om Den Ligestillede Frigjorte Hvide Danske Kvinde - og i forlængelse heraf Den Ligestillingsvenlige Hvide Danske Mand. Seksuel (u)tilgængelighed farver disse diskursive kategorier/ydersider. I relation til Den Muslimske Kvinde, så gestaltes 'hendes' frisættelse og kønsligestilling, af en dansk majoritetskultur, ofte som opnåelig gennem realisering af (forbudt) interracial intimitet. For Den Thailandske Kvinde er det selvsamme interraciale intimitetsrealisering, der mærker kategorien som problematisk, og positionerer 'hende' som købt, betalt og/eller uligestillet.

Fællesnævneren for begge kategorier er konstruktionen af mangelfuld og kulturelt 'upassende' seksualitet (alt for tilgxngelig eller slet ikke tilgængelig). Og det er her, spørgsmålet om forræderi bliver aktuelt i forbindelse med Den Thailandske Kvinde. Hvid, dansk majoritetskultur er i en vis forstand investeret i vedligeholdelse af denne figur, som (altid allerede) undertrykt og uligestillet for at kunne vedligeholde konstruktionen af Den Hvide Danske Kvinde som ligestillet og frigjort, men samtidig skyldspålægges Den Thailandske Kvinde også som forræder af netop normen om kønsligestilling: 'Figuren' tilskrives en seksuel excess, som hun forestilles at tilbyde hvide, danske mænd, der (måske) ikke gives mulighed for og/eller føler sig forpligtede på at opretholde en kollektiv social fantasi om kønsligestilling som realiseret princip.

I interviewmaterialets fortællinger pendles der mellem forskellige følelser, når thailandske kvinder italesættes og tematiseres: vrede, medlidenhed, foragt, distancering, fremmedgørelse, empati. Måske kan vi læse disse ambivalente emotionaliteter som sigende for netop figurens kompleksitet: Den Thailandske Kvinde som både 'offer' for patriarkatet og som 'forræder' af idealet om det Dorte Marie Søndergaard (1996) kalder "kulturens kønsegalitarisme."

\section{AT INSISTERE PÅ SIN EGEN FORTÆLLING}

De kvindelige informanter forhandler positioneringen som Thailandsk Kvinde på forskellige måder.

En informant, Therese, fortæller, at da hun var yngre, forsøgte hun ikke at være for nedringet og opknappet, når hun gik i byen. Dét, siger Therese, betød, at hun ikke så let blev anset som 'billig', men i stedet som lidt mere kostbar. Louise, en anden informant, fortæller, at da hun var teenager og tilbragte hver weekend på de lokale diskoteker, begyndte hun at gå i meget store og uformelige trøjer for ikke at blive opfattet som (hyper)seksuelt objekt. Louise omtaler selv strategien som et forsøg på 'at ligne lort'.

Hanne, som vi tidligere har mødt, har gjort sig erfaringer med net-dating. Noget hun kastede sig ud i, da hun var sidst $\mathrm{i}$ 20'erne, og før hun mødte sin nuværende mand. Hanne fortæller, at visse af hendes (hvide danske) dates måske har opfattet hende som en lettere scoring. Men når hun møder mænd, der har forestillinger om asiatiske kvinder som værende 'naturligt' underdanige, så “bliver de hurtigt bragt ind 
på rette vej. Så der er ingen bukken og skraben her." Da jeg spørger Hanne, hvordan hun făr afsendt et sådant signal, forklarer hun:

"Det tror jeg, det gair meget hurtigt op for dem (.) nesten fra man har sagt goddag. Jamen, den der indledende small talk (.) der fik jeg efterbainden sådan en indledning, kan man sige, nogle forord, hvor jeg ligesom fik sat nogle ting på plads.”

Da jeg spørger, hvad man fx kan sige, svarer Hanne:

"Jamen, jeg tror bare, det var, nair jeg fortalte om mig selv, fortalte om mit liv og nogle oplevelser, man har og sådan noget, hvor man siger, nej det finder jeg mig sgu ikke $i$, eller et eller andet. Den måde, det får udtryk på, gør måske også nogle gange, at folk tenker, narh ok hun er ikke sådan en type, der stiller sutskoene frem."

Hanne får altså foregrebet diverse forestillinger om asiatiske kvinder ved, ganske hurtigt når hun er på en date, at tilbyde sin egen fortælling om 'Hanne'. Disse 'forord' afskærmer hende mod at blive aflæst som 'underdanig' og 'uligestillet' kvinde. I stedet projiceres 'Hanne' over mod en kategori som selvstændig kvinde, der er i stand til at sige fra og ikke finde sig $\mathrm{i}$ hvad som helst.

De eksempler, som jeg her trækker frem kredser alle om (hetero)seksualiserede og romantiserede praksisfelter; diskoteket, gåen-i-byen, fester, den første date. De kredser ligeledes om - inden for ovennævnte praksisfelter - 'at sætte tegn' (Kofoed 2003, Staunæs 2003, Søndergaard 1996). Med udlægningen af tegn optegnes et handlerum, hvorfra der kan arbejdes tilbage på de racialiserede hyperseksualiseringsdynamikker. Nogle informanter sætter tegn, der søger at suspendere en positionering som seksuelt objekt, andre sætter tegn, der signalerer respektabelt eller kostbart seksuelt objekt, og endelig er der Hanne, som sætter tegn ved hurtigt at præsentere sine dates for en selvfortælling, der afmonterer eventuelle forestillinger om underdanig servicering.

Forhandlingsstrategierne erfares som mere eller mindre succesfulde. Louise husker, at selvom hun forsøgte 'at ligne lort', så var det ikke ensbetydende med, at hun slap for en positionering som hyperseksuelt objekt på diskoteket. For Hanne derimod erfares det at insistere på egen fortælling som mere effektfuldt. Måske fordi den voksne Hanne har gjort sig flere erfaringer med forhandling af romantisk og heteroseksuel intimitet, hvorimod teenageren Louise er ganske ny på diskoteket og står overfor at skulle indøve og tilegne sig praksisfeltets mange koder.

Det ikke umuligt at helt andre former for agens også konfigureres og afprøves. Her tænker jeg på aktører, der approprierer og meget aktivt tager hyperseksualiseringens konnotationer af promiskuøs seksualitet op som en form for subjektiverings- og modstandsprojekt. At der fra normalitetsperiferien formuleres agensformer, som netop trækker på og gencirkulerer konnotationerne af 'normalitetsafvigelse' og 'grænseoverskridelse'. Ingen af mine informanter fortæller om sådanne forhandlingsstrategier - men det gør dem langt fra utænkelige.

\section{ANALYSESTRATEGIENS ETIK}

Denne artikels læsninger og analytiske greb indkalder til refleksion over, hvorvidt og med hvilke effekter den valgte analysestrategi ikke blot forstyrrer men også risikerer at sedimentere Den Thailandske Kvinde som stigmatiserende subjektiveringsproces? Bliver det analytiske produkt en usolidarisk og eksklusionsproducerende læsning, som adskiller en kategori af koreansk adopterede kvinder fra Den Thailandske Kvinde gennem at påvise, at dette udgør en 'falsk' identitet og subjektivering? Og risikerer analysestrategien derved at bestyrke forestillinger om, at der eksisterer en 'xgte' 
identitet for koreansk adopterede, mens der eksisterer andre aktører, som på mere 'naturlig' vis hører hjemme i eller 'ejer' kategorien? Kommer læsningen til at understøtte herskende eksklusionsprocesser, hvor koreansk adopterede kvinder overordnes og 'renses' - for de (mis)tanker som konstruktionen af Den Thailandske Kvinde trækker med sig - gennem underordning og afgrænsning til andre asiatiske kvinder?

I den analytiske proces har jeg til stadighed måttet overveje spørgsmål som disse, og jeg har fundet inspiration hos Jette Kofoed, som skriver, at hun til sit analysearbejde om in- og eksklusionsprocesser i en skolekontekst formulerede en etik om, at analysearbejdet skulle forstyrre (frem for bidrage til) eksisterende eksklusioner (2003: 22). ${ }^{10}$ En sådan målsætning gælder også for denne artikel, om end jeg finder, at grænsen mellem de- og rekonstruktion, overskridelse og sedimentering, af herskende eksklusionsprocesser er vanskelig at balancere. Mine læsninger kan muligvis ikke undgå at spænde over både re- og dekonstruktion af diskursiv stigmatisering.

Jeg har dog forsøgt at pejle efter en analytisk etik, som først og fremmest forpligter mig på at undersøge og tydeliggøre de præmisser, som vanskeliggør og afskærer følelser af solidaritet. Det er på den baggrund, jeg har fremlæst Den Thailandske Kvinde som subjektiverende materialisering af en (kolonial) fantasi, som producerer andetgørende enshed mellem asiatisk og kvindeligt mærkede kroppe i en dansk kontekst. En fantasi der også kan begrebsliggøres som et magtfuldt disciplineringsredskab, der installerer hierarki og adskillelse mellem hvide kvinder og asiatiske kvinder og - især - fremmedgørelse og distancering mellem (minoriserede) asiatiske kvinder.

\section{AfsLutNing}

I denne artikel har jeg forsøgt at anskueliggøre, hvordan en racialiseret subjektiveringsproces som Den Thailandske Kvinde artikuleres gennem et hyperseksualiseret register. Forskellige konnotationer knytter sig til subjektiveringen, f.eks. købt, betalt og/ eller prostitueret. Sådanne subjektiveringer erfares af informanterne som magtfulde og fikserende, blandt andet fordi der i en dansk kontekst eksisterer et begrænset udbud af subjektiveringstilbud. I relation til dette har jeg foreslået, at distancering til Den Thailandske Kvinde kan læses som modstand og modvilje i forhold til at blive positioneret som et tilsyneladende offer. På et mere overordnet niveau kan man sige, at Den Thailandske Kvinde konstrueres som uligestillet og uligeværdig anden - alt det, som normativ dansk (hvid) femininitet ikke konstitueres af. Men jeg har også foreslået, at figuren samtidig forstyrrer og destabiliserer forestillinger om kønsligestilling som et realiseret ideal. Et ideal, der informerer dominerende kærlighedskonstruktioner i en dansk senmodernitet, og som kommer under pres, når et strukturelt og asymmetrisk magtforhold italesættes og tydeliggøres.

De kvindelige informanter indforstår sig i udbredt grad, ligesom majoriteten af yngre mennesker i Danmark født omkring eller efter 1970, med netop sådanne idealer. At blive positioneret som undertrykt eller offer er aldrig uproblematisk, fordi sådanne subjektpositioner kendetegnes af manglende agens og manglende værdighed. I den forstand kan vi læse de gentagne bevægelser af distancering til Den Thailandske Kvinde som en bestræbelse på at tage ejerskab og sikre tilhørsforhold til en (hvid) dansk femininitetsnorm, der kendetegnes af handlekraftighed, værdighed og ligestillethed, og dermed også som modstand og væring ved at blive indskrevet $\mathrm{i}$ en nationaliseret og racialiseret figur, der konnoterer destabilisering og forræderi af selvsamme norm.

Tak til Rasmus Præstmann Hansen for gode kommentarer og forslag til artiklen 


\section{NOTER}

1. Afhandlingen bygger på semi-strukturerede interviews med voksne koreansk adopterede informanter (20 kvinder og 15 mænd) født i perioden 1968-1981. Alle informanter er anonymiserede i artiklen.

2. Med en betegnelse som Den Thailandske Kvinde foretager jeg en reduktion af et diskursivt felt, der gennemkrydses og konstitueres af modsatrettede og skiftende diskurser om asiatisk femininitet i en dansk kontekst. Reduktionen er tænkt som et forsøg på analytisk begrebsliggørelse af dominerende og historisk sedimenterede diskurser, som reproduceres i en given kontekst, og som effekturerer forskellige former for subjektivering.

3. Jeg anvender i denne artikel betegnelser som 'asiatisk femininitet' og 'asiatisk kropstegn'. Beslutningen om at anvende 'asiatisk' er delvist informeret af, at det er denne terminologi, som informanterne anvender. På analytisk niveau kan en kategori som 'asiatisk' dog oplagt problematiseres som upræcis og reducerende. Menes der 'østasiatisk', 'vestasiatisk' og/eller 'sydøstasiatisk'? Kategorier som betydningskonstrueres på forskellige måder i en dansk kontekst. Denne skelnen kan dog også problematiseres. For hvilke (koloniale) præmisser informerer differentieringerne? I en dansk kontekst knyttes 'asiatisk' oftest til nationale og geografiske områder som eksempelvis Japan, Kina, Korea, Thailand og Vietnam. I langt mindre grad anvendes Asien og 'asiatisk' i forbindelse med Indien og Pakistan. Man kan spekulere over, om det især for sidstnævntes vedkommende skyldes, at en magtfuld kategori som 'muslim' dominerer, så den pakistanske befolkning først og fremmest identificeres som 'muslimsk' frem for 'vestasiatisk'? Lidt anderledes forholder det sig i en britisk kontekst, hvor Asian i højere grad konnoterer vestasiatisk. Man kan derfor - rettelig - indvende, at min anvendelse af 'asiatisk' reproducerer et sammenfald mellem Asien og 'syd/østasiatisk' i en dansk kontekst. På den anden side kan en diskursiv markering af 'syd/østasiatisk' også siges at producere et (ikke uproblematisk) skel til 'vestasiatisk'.

4. For eksempler på kvalitative studier udført i en dansk kønsforskningskontekst, som kvalificerer spørgsmålet om kønnet og etnificeret tilblivelse, se f.eks. Kleist (2007), Kofoed (2003), Mørck (1998) og Hansen (in prep.). For eksempler på studier hvor der arbejdes med begreber som etnisk-racialiseret tilblivelse, se Cawood (2007), Elg (2005), Jensen (2007) og Staunæs (2003).

5. Se Foucault (1990 [1976], 1982, 1972 [1969]) og Butler (1997a, 1997b, 1993, 1990)., 6. For andre kvalificeringer af subjektivering se
Cawood (2007), Juelskjær (2009), Kofoed (2003), Staunæs (2003), Sørensen (2005) og Frederiksen (2008)

7. I U.S. amerikanske studier af kønnede og racialiserede stereotypier gør andre kategorier sig gxldende, som ikke hæfter sig sammen med kategorier som 'Thailand'. Se f.eks. Kang (2002), Marchetti (1993), Tajima (1989) og Tuan (1999). For repræsentation og stigmatiserende mediefremstillinger af xgteskabsmigration fra Thailand til Danmark, se Baagøe Nielsen \& Gitz-Johansen (2006). 8. Sådanne dynamikker kendes også fra mange andre sammenhænge. Se f.eks. Staunæs (2003) der undersøger de eksklusionsprocesser, som luder-kategorien afstedkommer blandt 7. og 8. klasses skoleelever.

9. Her kan også henvises til Sarah Holst Kjærs disputats Sådan er det at elske. En kulturanalyse af parforhold (2009), som jeg først er blevet opmærksom på ved artiklens færdiggørelse. Holst Kjærs analyser kredser om de romantiske kærlighedskonstruktioner, der oppebærer urbane senmoderne (heteroseksuelle) parforhold i Danmark omkring 2000 -tallet. Kulturelle fantasier om ligeværd og fælles værdier får stor betydning. Parforholdsidealet er et harmonisk og eksklusivt match mellem to mennesker, hvor følelser, tanker og ønsker fremstår samtidige.

10. For beslægtede refleksioner omkring etnicitetsforskningens potentialer for at producere og understøtte usolidariske og stereotypiserende fortællinger, se også Jensen (2007), Prieur (1999) og Staunæs (2003).

\section{LITTERATUR}

- Andreassen, Rikke (2007): Der er et yndigt land. Medier, minoriteter og danskhed. Tiderne Skifter. - Andreassen, Rikke (2005). The Mass Media's Construction of Gender, Race, Sexuality, and Nationality: An Analysis of the Danish News Media Communication about Visible Minorities from 1971-2004. Ph.d.-afhandling. Department of History, University of Toronto.

- Berg, Anne-Jorunn (2004): Taus forlegenhet? Rasialisering, hvithet og minnearbeid, i Kvinneforskning 2004/2.

- Butler, Judith (1997a): The Psychic Life of Power. Theories in Subjection. Stanford University Press, Stanford, California.

- Butler, Judith (1997b). Excitable Speech: A Politics of the Performative. Routledge, New York. 
- Butler, Judith (1993): Bodies that Matter. On the Discursive Limits of "Sex". Routledge, New York, London.

- Butler, Judith (1990): Gender Trouble. Feminism and the Subversion of Identity. Routledge, New York, London.

- Baagøe Nielsen, Sten \& Gitz-Johansen, Thomas (2006). Mand i Migrationsegteskaber. Fortallinger om hverdag og vold $i$ danske monds samliv med udenlandske kvinder. Projekt ved Institut for Uddannelsesforskning, RUC og Minister for Ligestilling.

- Cawood, Sarah Højgaard (2007): Velkommen til Pussyland: Unge positionerer sig $i$ et seksualiseret medielandskab. Ph.d.-afhandling, Institut for Pædagogisk Psykologi, Danmarks Pædagogiske Universitetsskole.

- Dorow, Sara K. (2006): Transnational Adoption: A Cultural Economy of Race, Gender, and Kinship. New York University Press, New York, London.

- Elg, Camilla (2005): Set og overset. Unge kvinder med indvandrerbaggrund $i$ Danmark. Ph.d.-afhandling, Akademiet for Migrationsstudier i Danmark, Det Samfundsfaglige Fakultet, Aalborg Universitet.

- Foucault, Michel (1990 [1976]): The Will to

Knowledge. The History of Sexuality, vol. 1. Penguin Books, London.

- Foucault, Michel (1982): The Subject of Power, i Hubert L. Dreyfus \& Paul Rabinow (eds.): Michel Foucault. Beyond Structuralism and Hermeneutics. The University of Chicago Press, Chicago.

- Foucault, Michel (1972 [1969]): The Archaeology of Knowledge and the Discourse on Language.

Partheon Books, New York.

- Frankenberg (1993): White Women, Race Matters. The Social Construction of Whiteness. University of Minnesota Press, Minneapolis.

- Frederiksen, Maja Bissenbakker (2008): Dannelse og dissonanser. En normativitetskritisk undersøgelse af det danskfaglige curriculums subjektkonstruktioner specielt med henblik pa italesettelsen af kon og etnicitet. Ph.d.-afhandling, Institut for Nordiske Studier og Sprogvidenskab, Københavns Universitet.

- Hansen, Rasmus Præstmann (in prep.): www.autoboys.dk - mellem humor, biler og kroppe. En analyse af maskulinitets-og etnicitetskonstruktioner $i$ skolelivet på automekanikeruddannelsen. Ph.d.-afhandling, Afdeling for Pædagogik, Københavns Universitet.

- Holst Kjær, Sarah (2009): Sådan er det at elske. En kulturanalyse af parforhold. Museum Tusculanum.

· Hübinette, Tobias \& Tigervall, Carina (2008): Adoption med förhinder: Samtal med adopterade och adoptivföräldrar om vardagsrasism och etnisk identitet, Tumba: Mångkulturellt Centrum.

- Jensen, Sune Qvotrup (2007): Fremmed, frek og farlig. Unge mond og etnisk/racial andenhed - mellem modstand og stilisering. Ph.d.-afhandling, FREIA, Institut for Historie, Internationale Studier og Samfundsforhold, Aalborg Universitet.

- Juelskjær, Malou (2009): “En ny start” - Bevagelser i/gennem tid, rum, krop og sociale kategorier via begivenheden skoleskift. Ph.d.-afhandling, Institut for Læring, Danmarks Pædagogiske Universitetsskole, Aarhus Universitet.

- Kang, Laura Hyun Yi (2002): Compositional Subjects: Figuring Asian/American Women. Duke University Press, Durham, London.

- Kleist, Nauja (2007): Spaces of Recognition. An Analysis of Somali-Danish Associational Engagement and Diasporic Mobilization. Ph.d.-afhandling, Sociologisk Institut, Københavns Universitet. - Kofoed, Jette (2003): Elevpli: Inklusion-eksklusionsprocesser blandt børn $i$ skolen. Ph.d.-afhandling, Institut for Pædagogisk Psykologi, Danmarks Pædagogiske Universitet.

- Manalansan, Martin F. (2004): Global Divas: Filipino Gay Men in the Diaspora. Perverse Modernities.

- Marchetti, Gina (1993): Romance and the "Yellow Peril". Race, Sex, and Discursive Strategies in Hollywood Fiction. University of California Press, Berkeley, Los Angeles, London.

- Myong Petersen, Lene (2009): Adopteret-Fortallinger om transnational og racialiseret tilblivelse. Ph.d.-afhandling, Institut for Læring, Danmarks Pædagogiske Universitetsskole, Aarhus Universitet. - Mørck, Yvonne (1998): Bindestregsdanskere. Fortellinger om køn, generationer og etnicitet. Forlaget Sociologi.

. Omi, Michael \& Winant, Howard (1994 [1984]): Racial Formation in the United States. From the 1960s to the 1990s. Routledge, New York, London.

- Patton, Sandra (2000): BirthMarks. Transracial Adoption in Contemporary America. New York University Press, New York.

- Phoenix, Ann (2005): Remembered Racialization: Young People and Positioning in Differential Understandings, i Karim Murji \& John Solomos (eds.): Racialization. Studies in Theory and Practice. Oxford University Press, Oxford \& New York. - Prieur, Annick (1999): Maskulinitet, kriminalitet \& etnicitet, i Social Kritik 1999/65-66.

- Staunæs, Dorthe (2003). Køn, Etnicitet og skoleliv. Ph.d.-afhandling, Institut for Kommunikation, Journalistik og Datalogi, Roskilde Universitetscenter. 
- Søndergaard, Dorte Marie (2005): At forske i komplekse tilblivelser, i T. Bechmann Jensen \& G. Christensen (red.): Psykologiske og padagogiske metoder: Kvalitative og kvantitative forskningsmetoder $i$ praksis. Roskilde: Roskilde Universitetsforlag. - Søndergaard, Dorte Marie (2003): Subjektivering og nye identiteter, i Kvinder, Kon og Forskning 2003/4.

- Søndergaard, Dorte Marie (2002): Subjektivering og desire - begreber på empirisk arbejde i akademia, i Psyke o Logos 2002/1.

- Søndergaard, Dorte Marie (2000): Kønnet subjektivering: Forskerintroduktion, i Kvinder, Køn og Forskning 2000/1.

- Søndergaard, Dorte Marie (1996): Tegnet på kroppen. Køn: Koder og Konstruktion blandt voksne $i$ Akademia. Museum Tusculanums Forlag.

- Sørensen, Niels Ulrik (2005): Meget mere end metroseksuel. Krop, kon og identitet blandt unge mand $i$ den senmoderne massekultur. Ph.d.-afhandling, Forskerskolen i Livslang Læring, Roskilde Universitetscenter.

- Tajima, Renee (1989): Lotus Blossoms Don't Bleed: Images of Asian American Women, i Asian Women United: Making Waves: An Anthology of Writings By and About Asian Women. Beacon Press, Boston.

- Tuan, Mia (1999). Forever Foreigners or Honorary Whites: The Asian Ethnic Experience Today
SUMMARY

Becoming an equal Danish woman - narratives about race, gender and heterosexuality.

Drawing from a qualitative study on transnational adoption this article explores the question of racialized becoming in a Danish context. The analysis is based on interviews with adult female Korean adoptees, and it finds that discursively constructed categories of Asian femininity are marked by processes of hypersexualization. Hence, the interviewees negotiate subjectivity from intersections where colonial and racialized fantasies of Asian women, as both victims of patriarchy and inberently sexually promiscuous, clash with Danish ideals of gender equality. Ideals that are racialized as white.

Lene Myong Petersen

Ph.d.-stipendiat

Institut for Læring, Danmarks Pædagogiske

Universitetsskole

Aarhus Universitet. 